\section{Wibowo Romadhoni}

Mahasiswa Magister Ilmu Pemerintahan

Universtas Muhammadiyah Yogyakarta

\section{Ulung Pribadi}

Dosen Magister IImu Pemerintahan Universtas Muhammadiyah Yogyakarta Email: ulungpribadi@ymail.com

http://dx.doi.org/10.18196/ igpp.2014.0007

\section{Analisis Implementasi Anggaran Pembangunan Kelistrikan (Studi terhadap Perda APBD Sektor Pertambangan dan Energi Kabupaten Bulungan Tahun 2010-2012)}

\begin{abstract}
This research is descriptive research. Result research show do not have perda that special regulate about development electricity. success develop supporter factor implementation budget electricity can be seen from aspects implementation success scaling, namely: implementation policy support development budget in electricity development implementation. Support sources policy in Perda APBD mining sector implementation and Energi Kabupaten Bulungan with the existence of budget that is large and the increase human resource. Support communication inter related organisation, between Dinas Pertambangan and PT. PLN as well as BAPPEDA intertwined coordination that is good. Executive body characteristic, and tendency all executive appertain good with the existence of program-program activity that execute favorably. Executive activity very support so that target desired can achieved. Inside economy condition thing, social, and politics can be said that that aspect very support Implementasi success with all set him the need for energy electricity certainly will improve social and economic growth as well as stability politics. Factors that still become obstacle to Perda APBD Sektor Pertambangan success implementation and Energi Bulungan regency is executive apparatus number, facility and infrastructure still very less, inside inability contractor perform activity, and not smooth electricity in development because condition geography that is wide and out of reach.

Keyword: Policy implementation, Development Budget and Electricity.
\end{abstract}

\begin{abstract}
ABSTRAK
Penelitian ini adalah penelitian deskriptif.Hasil penelitian menunjukan belumada perda yang khusus mengatur tentang pembangunan kelistrikan.Faktor Pendukung keberhasilan implementasi anggaran pembanguan kelistrikan dapat dilihat dari aspek-aspek pengukuran keberhasilan implementasi, yaitu: dukungan kebijakan implementasi anggaran pembangunan dalam pelaksanaan pembangunan kelistrikan.Dukungan sumber-sumber kebijakan dalam implementasi Perda APBD Sektor Pertambangan dan Energi Kabupaten Bulungan dengan adanya anggaran yang besar dan peningkatan sumberdaya manusianya.Dukungan komunikasi antar organisasi terkait, antara Dinas Pertambangan dan PT. PLN serta BAPPEDA terjalin koordinasi yang baik.Karakteristik badan pelaksana, dan kecenderungan para pelaksana tergolong baik dengan adanya program-program kegiatan yang terlaksana dengan baik. Pelaksana kegiatan sangat mendukung agar target yang diinginkan dapat tercapai.Dalam hal kondisi ekonomi, sosial, dan politik dapat dikatakan bahwa aspek tersebut sangat mendukung keberhasilan Implementasi dengan tersedianya kebutuhan akan energi listrik tentunya akan meningkatkan pertumbuhan ekonomi dan sosial serta kestabilan politik.Faktor-faktor yang masih menjadi penghambat bagi keberhasilan implementasi Perda APBD Sektor Pertambangan dan Energi Kabupaten Bulungan adalah Jumlah aparat pelaksana, sarana dan prasarana masih sangat kurang, ketidakmampuan kontraktor dalam melaksanakan kegiatan, dan tidak meratanya pembangunan Kelistrikan karena kondisi geografi yang luas dan tidak terjangkau.

Kata Kunci: Implementasi Kebijakan, Anggaran Pembangunan dan Kelistrikan.
\end{abstract}




\section{PENDAHULUAN}

Listrik merupakan sumber penerangan dan energi yang punya peranan penting dalam roda kehidupan masyarakat di berbagai daerah. Begitu pula halnya dengan masyarakat di Kabupaten Bulungan. Produksi listrik di Kabupaten Bulungan selama kurun waktu 2007-2009 mengalami kenaikan yaitu dari hanya 33.158.098 KWh menjadi 38.595.691 KWh pada tahun 2009. Sejalan dengan peningkatan produksi listrik, jumlah listrik yang didistribusikan juga cenderung meningkat. Jumlah listrik yang didistribusikan pada tahun 2007 tercatat sebesar 31.944.564 KWh. Angka ini meningkat menjadi 37.878.403 KWh pada tahun 2009 (BPS Kabupaten Bulungan, 2010).

Sebagian besar kebutuhan listrik di Kabupaten Bulungan dipenuhi oleh PT Perusahaan Listrik Negara (PLN). Sementara sebagian lagi disuplai secara swasembada oleh masyarakat dan pemerintah daerah. Peningkatan terhadap kebutuhan listrik tentunya membutuhkan pengaturan yang baik agar dapat terpenuhi. Pengaturan tersebut kemudian dilakukan melalui berbagai kebijakan yang berhubungan dengan pembangunan kelistrikan. Salah satu faktor penting dalam upaya pembangunan kelistrikan berhubungan dengan anggaran dan pembiayaan. Kebijakan yang mengatur tentang anggaran dan pembiayaan pembangunan kelistrikan adalah Perda Anggaran Pendapatan dan Belanja Daerah (APBD) Kabupaten Bulungan. Perda APBD memuat adanya rencana pembangunan sarana kelistrikan, pembangunan pembangkit listrik, pengembangan jariangan listrik, dan lain sebagainya.

Implementasi terhadap Perda APBD tentunya akan mendukung pembangunan kelistrikan di Kabupaten Bulungan. Apabila Perda APBD diimplementasikan dengan baik, tentunya pembangunan kelistrikan di Kabupaten Bulungan juga berjalan dengan lancar sehingga tercipta kepuasan bagi masyarakat pengguna. Fakta di lapangan masih menunjukkan berbagai permasalahan terkait 
implementasi pembangunan kelistrikan. Masyarakat masih banyak memberikan keluhan terhadap pelayanan listrik di Kabupaten Bulungan. Keluhan diantaranya seringnya pemadaman listrik dan rendahnya tegangan listrik. Dalam rencana pembangunan kelistrikan yang terdapat dalam APBD Kabupaten Bulungan dapat diketahui bahwa alokasi dana yang akan digunakan dalam pembangunan sarana dan fasilitas kelistrikan cukup besar. Akan tetapi, pembangunan kelistrikan belum dijalankan dengan efektif berarti ada permasalahan dalam implementasi Perda APBD Kabupaten Bulungan.

Implementasi kebijakan pengembangan kelistrikan mengalami berbagai kendala di lapangan. Kendala tersebut dapat berasal dari peningkatan kebutuhan masyarakat akan energi listrik, tidak jalannya pembangunan kelistrikan ketika sampai di lapangan, dan lain sebagainya. Permasalahan yang akan dikaji dalam penelitian ini dirumuskan yakni Bagaimana implementasi anggaran pembangunan kelistrikan berdasarkan Perda APBD sektor pertambangan dan energi Kabupaten Bulungan tahun 2010-2012? dan Faktor-faktor apa saja yang mendukung (supplementary factors) dan yang menghambat (resistor factors) keberhasilan implementasi anggaran pembangunan kelistrikan berdasarkan Perda APBD sektor pertambangan dan energi Kabupaten Bulungan tahun 2010-2012?

\section{KERANGKA TEORI}

\section{DEFINISI KEBIJAKAN}

Istilah kebijakan biasanya digunakan untuk perbuatan yang baik, menguntungkan atau positif. Sedangkan policy berasal dari bahasa Latin "politeia" yang berarti kewarganegaraan. Karena policy dikaitkan dengan pemerintahan, maka lebih tepat jika diterjemahkan sebagai kebijaksanaan dan kebijakan (Suryaningrat, 1999: 11). Berbeda dengan Winarno (2008: 14), bahwa istilah kebijakan digunakan untuk menunjuk perilaku seorang aktor (misalnya seorang pejabat, 
suatu kelompok, maupun suatu lembaga pemerintah) atau sejumlah aktor dalam suatu bidang kegiatan tertentu

\section{ANGGARAN PENDAPATAN DAN BELANJA DAERAH (APBD)}

Anggaran merupakan rencana yang diwujudkan dalam besaran uang, sedangkan penganggaran adalah proses untuk menyusun anggaran.

\section{TABEL 1: IDENTIFIKASI KEBUTUHAN ANGGARAN}

\begin{tabular}{ll}
\hline Sebagai Alat & Anggaran digunakan sebagai alat untuk menetapkan kehendak \\
Perencanaan & $\begin{array}{l}\text { pemerintah untuk meningkatkan kesejahteraan rakyat (public } \\
\text { welfare) dengan jalan memanfaatkan sumberdaya dan dana } \\
\text { untuk mendukung kegiatan pembangunan jangka panjang } \\
\text { dalam bentuk anggaran tahunan (annual budget), }\end{array}$ \\
& Anggaran digunakan sebagai alat pengendalian yang efektif, \\
Sebagai Alat & sehingga dilakukan secara melekat (built in control) dalam \\
Pengendalian & tubuh organisasi atas berlangsungnya pelaksanaan kegiatan \\
Sebagai Alat & Kinerja setiap pelaksana kegiatan dapat diukur dan dievaluasi \\
Evaluasi & secara periodik maupun insidentil, yaitu: (1) Apakah sudah \\
& sesuai dengan rencana kegiatan anggaran, (2) Apakah tidak \\
& menyimpang dari peraturan perundang-undangan, (3) Apakah \\
& sudah dilaksanakan secar efisien, efektif berdasarkan \\
& pembanding yang sejenis.
\end{tabular}

Sumber: Bastian (2006: 165)

\section{METODE PENELITIAN}

Penelitian ini adalah penelitian deskriptif. Menurut Arikunto (2010: 291), penelitian deskriptif tidak dimaksudkan untuk menguji hipotesis tertentu, tetapi hanya menggambarkan apa adanya, tentang suatu variabel, gejala atau keadaan. Dengan demikian dapat dikatakan bahwa penelitian ini merupakan penelitian deskriptif kualitatif.

Keberhasilan suatu penelitian di tentukan oleh teknik pengumpulan data yang dipergunakan oleh peneliti. Menurut Arikunto (2010: 265) metode pengumpulan data ada dua, yaitu metode tes dan non tes. Metode non tes meliputi kuisioner, interview, angket, observasi, dan dokumentasi. 


\section{PEMBAHASAN}

\section{IMPLEMENTASI ANGGARAN PEMBANGUNAN KELISTRIKAN}

Implementasi anggaran kelistrikan dapat diketahui melalui datadata yang telah dikumpulkan dalam proses penelitian Implementasi Anggaran Pembangunan Kelistrikan peneliti menggunakan model Implementasi kebijakan didasarkan pada teori yang dikemukakan Van Metter dan Van Horn. sebagai berikut:

A. UKURAN DAN TUJUAN KEBIJAKAN IMPLEMENTASI

PEMBANGUNAN KELISTRIKAN

Dengan melihat gambaran dan identifikasi permasalahan pembangunan kelistrikan di Kabupaten Bulungan, dengan memperhatikan visi dan misi serta 4 skala prioritas, maka ditetapkan Tujuan kebijakan sebagai berikut.

1. Peningkatan sumberdaya manusia sarana dan prasarana

2. Peningkatan penyediaan distribusi jaringan listrik

3. Pelayanan perijinan di bidang pertambangan umum yang akuntabel

4. Pengawasan di bidang pertambangan umum dan energi yang lebih intensif

Indikator dari ukuran dan tujuan kebijakan adalah sasaran kebijakan, kecermatan kebijakan, kejelasan kebijakan, dan kepuasan masyarakat terhadap implementasi kebijakan.

Hasil analisis deskriptif menunjukkan bahwa mayoritas sebanyak 33 orang $(94,3 \%)$ dari total responden menyatakan bahwa ukuran dan tujuan kebijakan mengenai anggaran kelistrikan tergolong baik. Tabel dan grafik di atas juga menunjukkan bahwa terdapat 2 orang responden $(5,7 \%)$ yang menyatakan bahwa ukuran dan tujuan kebijakan tergolong sangat baik.

Apabila dilihat dari sasaran kebijakan dapat dikatakan bahwa sasaran pembangunan kelistrikan cukup jelas sebagaimana tertuang dalam salah satu visi dan misi Dinas Pertambangan dan Energi 

KEBIJAKAN

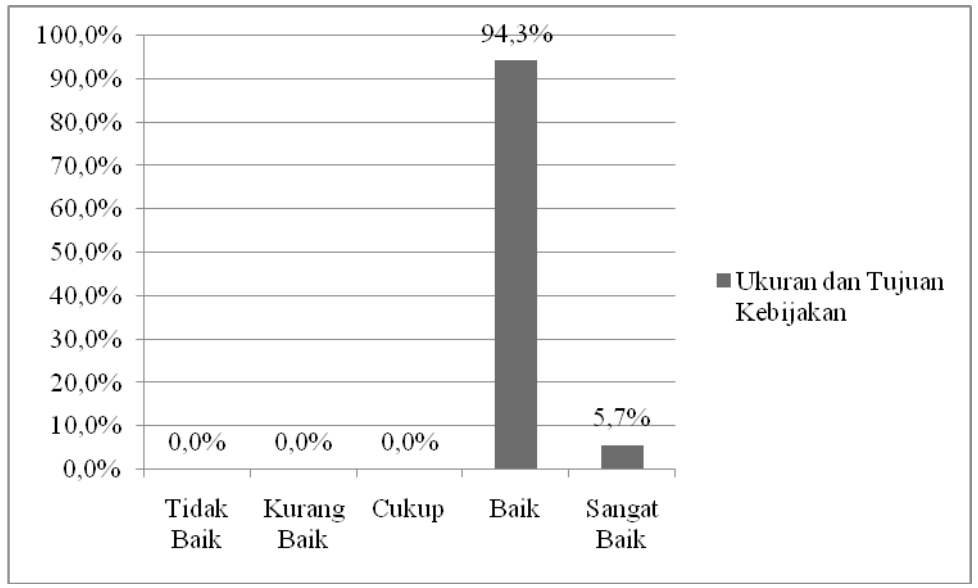

TABEL 2 UKURAN DAN TUJUAN KEBIJAKAN

\begin{tabular}{|c|c|c|c|}
\hline Nilai & Pejabat Dinas & Masyarakat & Swasta \\
\hline Cukup & - & - & - \\
\hline Baik & 33 & 33 & 32 \\
\hline Sangat baik & 2 & 2 & 3 \\
\hline Total & 35 & 35 & 35 \\
\hline Chi Square $\left(\chi_{\text {hitung }}{ }^{2}\right)$ & & 7.722 & 22.626 \\
\hline Asymp. Sig. & & 0.005 & 0.000 \\
\hline$\chi 2 \operatorname{tabel}_{(0.95)}=$ & & 3.84 & 3.84 \\
\hline
\end{tabular}

Sumber: data diolah (2013)

Kabupaten Bulungan, yaitu peningkatkan penyediaan distribusi jaringan listrik. Dalam hal kejelasan kebijakan dapat dikatakan bahwa program kelistrikan yang disusun dan dilaksanakn oleh Dinas Pertambangan dan Energi cukup jelas. Hal ini dapat dilihat dari laporan proyek pengerjaan program pembangunan kelistrikan. Begitu pula halnya dengan kepuasan masyarakat. Kepuasan masyarakat tentunya mengalami peningkatan terkait distribusi jaringan listrik yang semakin meluas hingga ke desa-desa. Hasil 
analisis Chi Square terhadap jawaban responden mengenai ukuran dan tujuan kebijakan dapat dilihat pada tabel berikut.

Tabel 2 menunjukkan nilai $\div_{\text {hitung }}^{2}=7,722$ dengan nilai P sebesar 0,005 untuk perbedaan antara pendapat Dinas dengan masyarakat dan 22,626 dengan nilai P sebesar 0,000. Adapun nilai $\div_{\text {tabel }}^{2}$ pada taraf kesalahan 5\% adalah sebesar 3,84 untuk kedua pengujian. Berdasarkan hasil pengujian tersebut dapat diketahui bahwa $\div_{\text {hitung }}^{2}>\div_{\text {tabel }}^{2}$, yaitu 7,722>3,84 dan 22,262>3,84 dengan nilai P > 0,05 . Dengan demikian, dapat dikatakan bahwa Ho ditolak dan $\mathrm{Ha}$ diterima. Penerimaan Ha tersebut menunjukkan bahwa ada hubungan antara pendapat Dinas dengan masyarakat maupun antara pendapat Dinas dengan piha swasta. Berdasarkan hasil wawancara dengan informan diperoleh fakta bahwa fasilitas kelistrikan sudah memadai meskipun belum terpenuhi secara keseluruhan. Cukup baik atau seimbang dan harus terus ditingkatkan baik dari sektor kebijakan maupun implementasi agar dapat mendekati kebutuhan daerah atau masyarakat dan pemeliharaan hasil implementasi juga harus ditingkatkan. Pemda Kabupaten Bulungan tetap menindaklanjutisecara bertahap, sesuai ketersediaan anggaran melalui APBD, APBD Propinsi dan APBN.(Hasil Wawancara Informan 1 dan 3, 2013).

Dapat dipahami bahwa ukuran kebijakan sudah cukup seimbang. Selain ukuran, kebijakan tentunya juga memiliki tujuan yang akan dicapai. Tujuan implementasi Perda APBD Sektor Pertambangan dan Energi Kabupaten Bulungan dalam rangka pemenuhan kebutuhan penerangan sampai masyarakat pedesaan dan sebagai faktor pendukung pembangunan pengembangan masyarakat, pemerataan, dan investasi bidang pertambangan, pertanian, dan perkebunan. (Hasil Wawancara Informan 1, 2013).

Kebijakan mengenai Perda APBD Sektor Pertambangan dan Energi Kabupaten Bulungan memiliki tujuan untuk memenuhi kebutuhan penerangan hingga ke pedesaan dan juga diperlukan 
sebagai faktor pendukung pembangunan khususnya di bidang kelistrikan. Dari implementasi yang terjadi di lapangan dapat diketahui bahwa implementasi Perda APBD Sektor Pertambangan dan Energi Kabupaten Bulungan sudah hampir sesuai dengan yang diharapkan. Kebijakan yang diambil merujuk kepada kebutuhan masyarakat melalui Musrembang, pelaksanaan, atau implementasi (realisasi fisik) di lapangan juga mendekati sempurna. Walaupun harus ada perbaikan dan peningkatan di kedua sektor (Hasil Wawancara Informan 3, 2013).

\section{SUMBER-SUMBER KEBIJAKAN IMPLEMNTASI ANGGARAN PEMBANGUNAN KELISTRIKAN}

Implementasi kebijakan tentunya memerlukan sumberdaya. Keberhasilan proses implementasi kebijakan Perda APBD Sektor Pertambangan dan Energi Kabupaten Bulungan sangat tergantung dari kemampuan memanfaatkan sumberdaya yang tersedia. Sumberdaya yang dibutuhkan antara lain sumberdaya manusia, sumber keuangan, serta fasilitas. Selain kecukupan jumlah atau kuantitas, terntunya diharapkan sumberdaya yang tersedia juga memiliki kualitas yang baik. Penilaian responden terhadap sumber-sumber kebijakan dapat juga digambarkan sebagaimana berikut: (lihat grafik)

Dapat dipahami bahwa dari pendapat mayoritas responden yang termasuk dalam interval kategori baik, yaitu sebanyak 23 orang $(65,7 \%)$. Pada dasarnya sumber-sumber kebijakan terdiri dari sumberdaya manusia, sumberdaya keuangan, dan fasilitas. Sumberdaya manusia dapat dikatakan sudah mencukupi baik dalam jumlah maupun dalam kompetensi. Sumberdaya manusia yang melaksanakan kebijakan merupakan sumberdaya manusia yang kompeten di bidang kelistrikan. Begitu pula halnya dengan sumberdaya keuangan dan fasilitas

Hasil analisis Chi Square terhadap jawaban responden mengenai sumber-sumber kebijakan dapat dilihat pada tabel berikut. 
GRAFIK 2 PROPORSI PENDAPAT RESPONDEN TENTANG SUMBER-SUMBER KEBIJAKAN

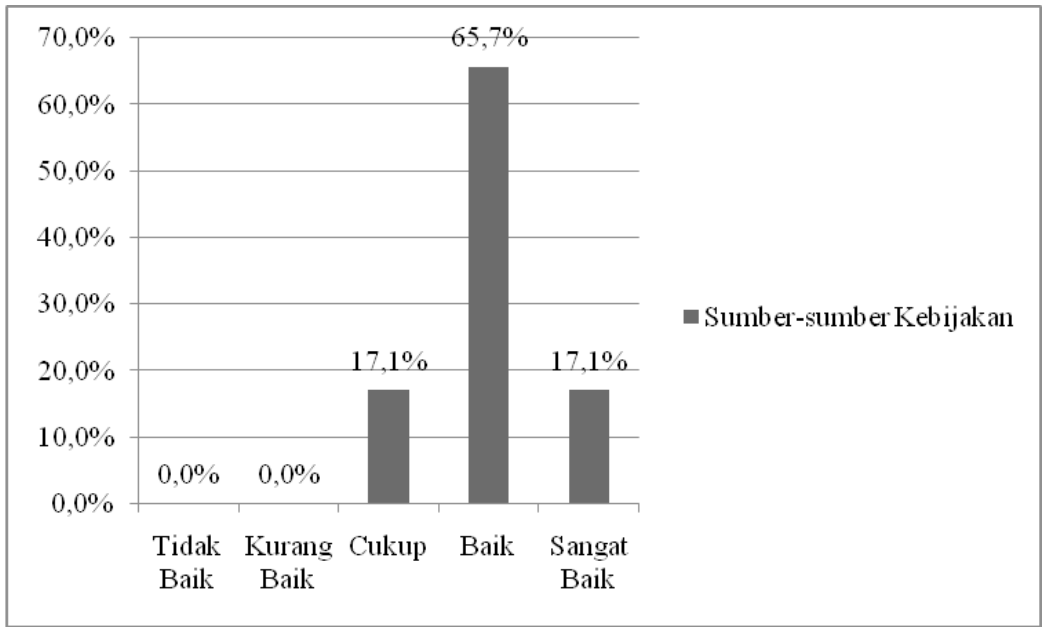

TABEL 3 SUMBER-SUMBER KEBIJAKAN

\begin{tabular}{llll}
\hline Nilai & Pejabat Dinas & Masyarakat & Swasta \\
\hline Cukup & 6 & 9 & 7 \\
Baik & 23 & 21 & 23 \\
Sangat baik & 6 & 5 & 5 \\
Total & 35 & 35 & 35 \\
Chi Square & & 37.892 & 26.740 \\
Asymp. Sig. & & 0.000 & 0.000 \\
X2tabel $_{(0.95)}=$ & & 9.49 & 5.99 \\
\hline
\end{tabular}

Sumber: data diolah (2013)

Tabel di atas menunjukkan nilai $\div_{\text {hitung }}^{2}=37,892$ dengan nilai $\mathrm{P}$ sebesar 0,000 untuk perbedaan antara pendapat Dinas dengan masyarakat dan 26,740 dengan nilai $\mathrm{P}$ sebesar 0,000. Adapun nilai $\div_{\text {tabel }}^{2}$ pada taraf kesalahan 5\% adalah sebesar9,49 untuk kedua pengujian. Berdasarkan hasil pengujian tersebut dapat diketahui bahwa $\div{ }_{\text {hitung }}^{2}>\div{ }_{\text {tabel }}^{2}$, yaitu 37,892 > 9,49 dan 26,740 > 9,49 dengan nilai $\mathrm{P}>0,05$. Dengan demikian, dapat dikatakan bahwa Ho ditolak dan Ha diterima. Penerimaan Ha tersebut menunjukkan bahwa ada 
hubungan antara pendapat Dinas dengan masyarakat maupun antara pendapat Dinas dengan piha swasta dalam hal sumber-sumber kebijakan.

Pada dasarnya sumberdaya manusia dapat dikatakan sudah memadai dalam implementasinya sesuai dengan tenaga teknis dalam bidangnya.Perlu ditingkatkan kualitas dan pengalaman di lapangan melalui pelatihan dan bimbingan teknis. Dalam hal sumberdaya keuangan dapat dipahami bahwa pelaksanaan implementasi kebijakan mengenai Perda APBD Sektor Pertambangan dan Energi Kabupaten Bulungan telah dilaksanakan sesuai dengan anggaran yang ditetapkan. Diketahui bahwa sumberdaya keuangan yang dianggarkan sudah cukup memadai walaupun belum mencakup semua kebutuhan masyarakat. Namun secara bertahap terus ditingkatkan agar anggaran yang tersedia dapat memenuhi target kebutuhan masyarakat. (Hasil Wawancara Informan 3, 2013).

Dalam hal fasilitas, sumberdaya kebijakan dapat dikatakan sudah cukup memadai.Fasilitas yang ada cukup baik, ditinjau dari segi administrasi, sedangkan peralatan pendukung harus terus ditingkatkan. Khusus mengenai pembangunan kelistrikan fasilitas pendukung yang penting ketika pemeriksaan barang dan saat perangkat tersebut terpasang. Penggunaan badan-badan resmi untuk SLO dan kerjasama (pemeriksaan bersama PT. PLN-SLO).Masih diperlukan peningkatan peralatan pendukung terutama dalam pembangunan kelistrikan (Hasil Wawancara, 3, 2013).

\section{KOMUNIKASI ANTAR ORGANISASI TERKAIT DENGAN KEGIATAN-KEGIATAN PELAKSANAAN}

Komunikasi organisasi merupakan koordinasi antar dinas Pertambangan Dan Energi kabupaten Bulungan selalu berkomunikasi dengan penyedia sumber energi dan pengelola kelistrikan, PT. PLN (Persero) Wilayah Kaltim Cabang Berau Ranting Tanjung Selor sebagai Penyedia Energi listrik,Komunikasi ini 
dilakukan dalam rangka perencanaan dan skala kebutuhan serta konsultasi teknik tentang standar pelayanan dalam kelistrikan. Komunikasi ini dijalin dengan baik demi terciptanya kemajuan guna memakmurkan masyarakatrnya.

\section{GRAFIK 3 PROPORSI PENDAPAT RESPONDEN TENTANG KOMUNIKASI ANTAR ORGANISASI TERKAIT}

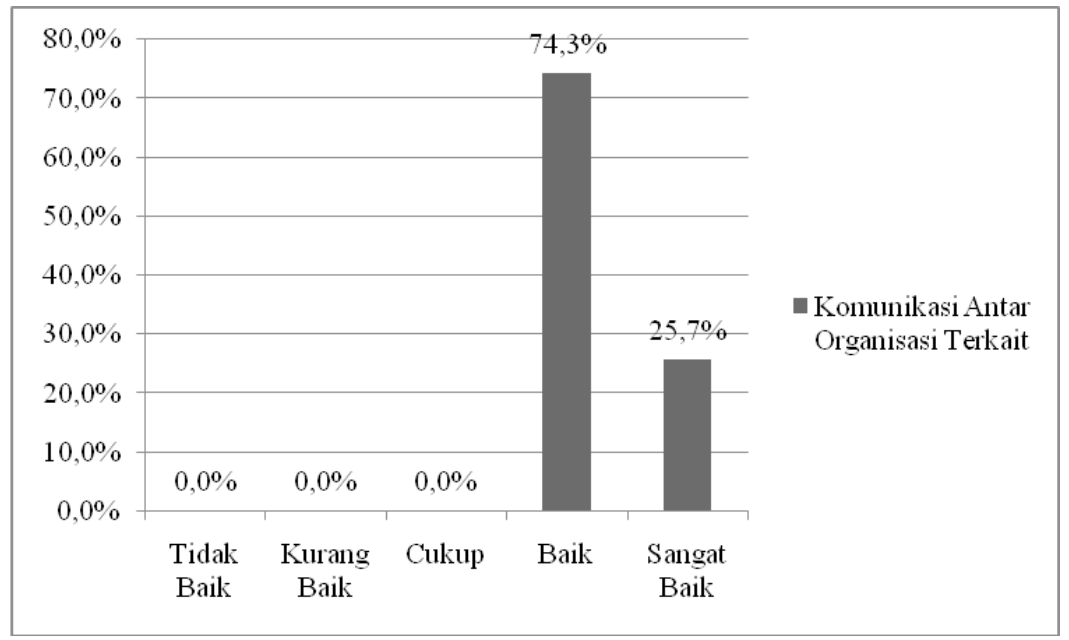

Komunikasi antara organisasi terkait dilakukan melalui rapat koordinasi antara Dinas Pertambangan dan Energi dengan PT. PLN (Persero) Wilayah Kaltim Cabang Berau Ranting Tanjung Selor dan instansi teknis lainnya. Rapat yang dilakukan dengan PT. PLN (Persero) Wilayah Kaltim Cabang Berau Ranting Tanjung Selor hanya bersifat konsultasi. Rapat yang bersifat penyusunan rencana bersama dilakukan dengan pihak-pihak swasta yang terkait dengan pembangunan kelistrikan. Jumlah responden dengan pendapat mengenai komunikasi antar organisasi terkait yang tergolong baik adalah sebanyak 26 orang (74,3\%)yang Hasil Analisis Chi Squareterhadap jawaban responden mengenai komunikasi antar organisasi dapat dilihat pada tabel berikut. 
TABEL 4 KOMUNIKASI ANTAR ORGANISASI

\begin{tabular}{llll}
\hline Nilai & Pejabat Dinas & Masyarakat & Swasta \\
\hline Cukup & - & - & - \\
Baik & 26 & 27 & 26 \\
Sangat baik & 9 & 8 & 9 \\
Total & 35 & 35 & 35 \\
Chi Square & & 16.490 & 10.637 \\
& Asymp. Sig. & 0.000 & 0.000 \\
Z2tabel $_{(0.95)}=$ & & 3.84 & 3.84 \\
\hline
\end{tabular}

Sumber: data diolah (2013)

Tabel di atas menunjukkan nilai $\dot{\leftarrow}_{\text {hitung }}^{2}=16,490$ dengan nilai $\mathrm{P}$ sebesar 0,000 untuk perbedaan antara pendapat Dinas dengan masyarakat dan 10,637 dengan nilai P sebesar 0,000. Adapun nilai $\div_{\text {tabel }}^{2}$ pada taraf kesalahan 5\% adalah sebesar3,84 untuk kedua pengujian. Berdasarkan hasil pengujian tersebut dapat diketahui bahwa $\div_{\text {hitung }}^{2}>\div{ }_{\text {tabel }}^{2}$, yaitu 16,490 > 3,84 dan 10,637 > 3,84 dengan nilai $\mathrm{P}>0,05$. Dengan demikian, dapat dikatakan bahwa Ho ditolak dan Ha diterima. Penerimaan Ha tersebut menunjukkan bahwa ada hubungan antara pendapat Dinas dengan masyarakat maupun antara pendapat Dinas dengan piha swasta dalam hal komunikasi antar organisasi.

"Komunikasi terhadap anggaran melalui mekanisme-mekanisme yang sudah ditetapkan. Setiap usulan sampai menjadi Perda diharapkan sudah digodok dalam mekanisme tersebut. maka, komunikasi melalui rapat-rapat pembahasan atau komunikasi sudah cukup baik dengan selalu melibatkan pihak-pihak terkait" (Hasil Wawancara Informan 3, 2013).

Dapat dipahami bahwa komunikasi antara penyusun Perda APBD Sektor Pertambangan dan Energi Kabupaten Bulungan tahun 2010-2012 dengan Dinas pertambangan dan Energi sebagai dinas 
pelaksana sudah terbilang cukup baik. komunikasi ini dilaksanakan sesuai dengan mekanisme yang telah ditetapkan sebelumnya. Adapun bentuk komunikasi tersebut adalah melalui rapat-rapat pembahasan perda. Begitu pula halnya dengan komunikasi antara Dinas Pertambangan dan Energi sebagai dinas pelaksana dengan masyarakat. Komunikasi dilakukan oleh Dinas Pertambangan dan Energi dengan pihak swasta pelaksana lapangan.

"Komunikasi dinas kepada masyarakat dan sebaliknya cukup baik. dari proses usulan sampai dengan pelaksanaan, sampai dengan masa pemeliharaan, pembangunan jaringan listrik, selalu masyarakat dilibatkan dalam komunikasi yanh baik" (Hasil Wawancara Informan 3, 2013).

\section{KARAKTERISTIK BADAN-BADAN PELAKSANA}

Karakteristik badan pelaksana merupakan salah satu faktor yang sangat penting akan sangat banyak dipengaruhi oleh ciri-ciri yang tepat serta kesesuaian dengan Dinas Pertambangan dan Energi sebagai agen pelaksananya. Indikator dari karakteristik badan-badan pelaksana adalah kualitas, komitmen, dan sifat. Penilaian responden mengenai karakteristik badan pelaksana dalam diketahui dari hasil kuesioner berikut.

\section{GRAFIK 4 PROPORSI PENDAPAT RESPONDEN TENTANG KARAKTERISTIK BADAN PELAKSANA}

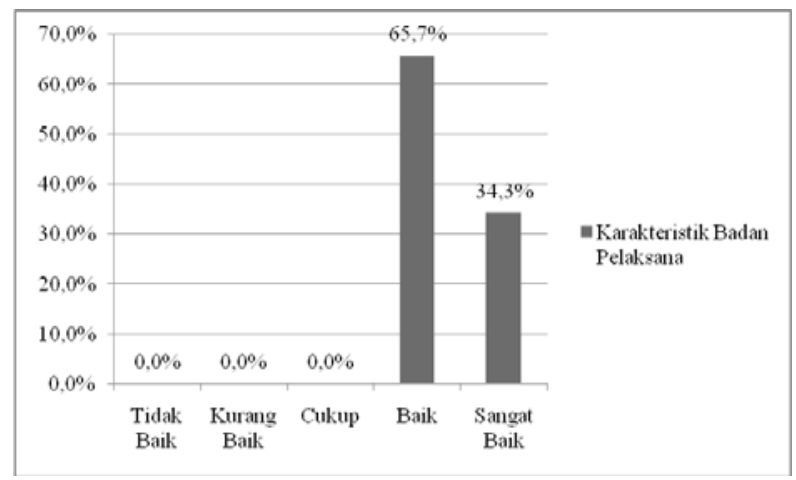


Berdasarkan hasil kuesioner di atas dapat dipahami bahwa karakteristik badan pelaksana Perda APBD Sektor Pertambangan dan Energi Kabupaten Bulungan sudah tergolong baik. Hal ini diketahui dari jawaban mayoritas responden terhadap aspek-aspek karakteristik badan pelaksana yang tergolong dalam kategori baik, yaitu sebanyak 23 orang $(65,7 \%)$. Hasil analisis Chi Square terhadap jawaban responden mengenai Karakteristik badan pelaksana dapat dilihat pada tabel berikut.

TABEL 5 KARAKTERISTIK BADAN PELAKSANA

\begin{tabular}{llll}
\hline Nilai & Pejabat Dinas & Masyarakat & Swasta \\
\hline Cukup & - & - & 1 \\
Baik & 23 & 21 & 19 \\
Sangat baik & 12 & 14 & 15 \\
Total & 35 & 35 & 35 \\
Chi Square & & 20.311 & 17.776 \\
Asymp. Sig. & & 0.000 & 0.000 \\
Z2tabel $_{(0.95)}=$ & & 3.84 & 5.99 \\
\hline
\end{tabular}

Sumber: data diolah (2013)

Tabel di atas menunjukkan nilai $\dot{\mathrm{h}}_{\text {hitung }}^{2}=20,311$ dengan nilai $\mathrm{P}$ sebesar 0,000 untuk perbedaan antara pendapat Dinas dengan masyarakat dan 17,776 dengan nilai P sebesar 0,000. Adapun nilai $\div_{\text {tabel }}^{2}$ pada taraf kesalahan 5\% adalah sebesar3,84 untuk pengujian pertama dan 5,99 untuk pengujian kedua. Berdasarkan hasil pengujian tersebut dapat diketahui bahwa $\div{ }_{\text {hitung }}^{2}>\div$ tabel ${ }^{2}$, yaitu 20,311 $>$ 3,84 dan 17,776> 5,99 dengan nilai $\mathrm{P}>0,05$. Dengan demikian, dapat dikatakan bahwa Ho ditolak dan Ha diterima. Penerimaan Ha tersebut menunjukkan bahwa ada hubungan antara pendapat Dinas dengan masyarakat maupun antara pendapat Dinas dengan piha swasta dalam hal karakteristik badan pelaksana

Dinas Pertambangan dan Energi Kabupaten Bulungan 
merupakan instansi teknis pelaksana. Melalui instansi tersebut, masyarakat memiliki harapan yang sangat besar agar fasilitas penerangan segera terpenuhi. Karakteristik badan pelaksana juga dapat dipahami dari visi dan misi.Sesuai visi dan misi dinas, maka karakter dinas adalah mensukseskan atau mengimplementasikan APBD dengan baik, benar, aman, lancar, selalu memperbaiki kinerja, meningkatkan kualitas pekerjaan, dan sanggup mengamankan hasil pekerjaan agar berguna dan dapat dinikmati terus menerus. (Hasil Wawancara Informan 3, 2013).

Dalam pelaksanaannya, berbagai program pembangunan kelistrikan kemudian melibatkan beberapa instansi yang terkait dan juga pihak-pihak perusahaan. Dalam pembangunan jaringan listrik, pihak Dinas Pertambangan dan Energi melakukan koordinasi dengan PT. PLN, dan juga dengan beberapa pihak swasta. Keterlibatan pihak swasta dalam pembangunan kelistrikan di Kabupaten Bulungan disebabkan proyek pembangunan kelistrikan dilelang kepada pihak swasta.

\section{GRAFIK 5 PROPORSI PENDAPAT RESPONDEN TENTANG KONDISI EKONOMI, SOSIAL, DAN POLITIK}

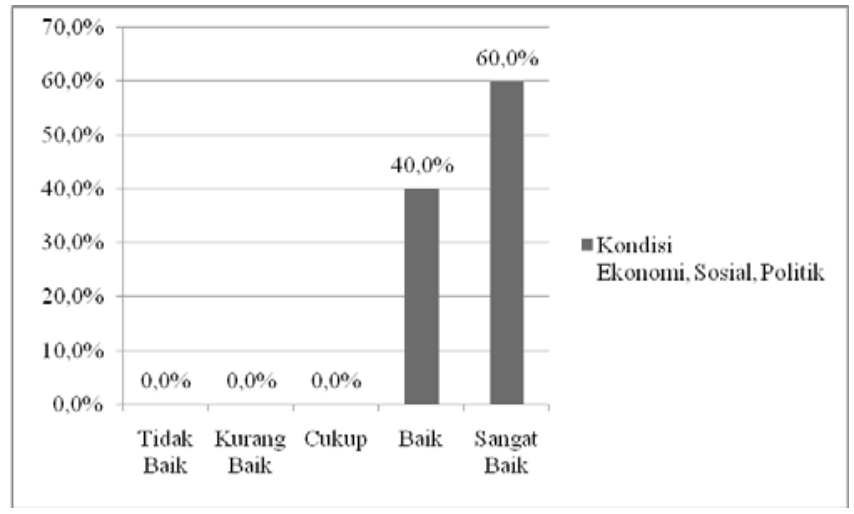

\section{KONDISI-KONDISI EKONOMI, SOSIAL, DAN POLITIK}

Kondisi-kondisi ekonomi diuraikan berdasarkan ekonomi, sosial, 
dan politik. Penilaian informan terhadap kondisi ekonomi, sosial, dan politik diuraikan sebagaimana tabel berikut.Proporsi pendapat responden mengenai kondisi ekonomi, sosial, dan politik dapat juga digambarkan sebagaimana berikut. (lihat grafik 5)

Berdasarkan tabel di atas dapat dipahami bahwa kondisi sosial, ekonomi, dan politik yang dapat mempengaruhi implementasi dan tergolong baik, bahkan sangat baik. Hasil analisis Chi Square terhadap jawaban responden mengenai Kondisi sosial, ekonomi, dan politik dapat dilihat pada tabel berikut.

TABEL 6 KONDISI SOSIAL, EKONOMI, DAN POLITIK

\begin{tabular}{llll}
\hline Nilai & Pejabat Dinas & Masyarakat & Swasta \\
\hline Cukup & - & - & 2 \\
Baik & 14 & 14 & 13 \\
Sangat baik & 21 & 21 & 20 \\
Total & 35 & 35 & 35 \\
Chi Square & & 14.464 & 12.676 \\
Asymp. Sig. & & 0.000 & 0.002 \\
Z2tabel $_{(0.95)}=$ & & 3.84 & 5.99 \\
\hline
\end{tabular}

Sumber: data diolah (2013)

Tabel di atas menunjukkan nilai $\div_{\text {hitung }}^{2}=14,464$ dengan nilai $\mathrm{P}$ sebesar 0,000 untuk perbedaan antara pendapat Dinas dengan masyarakat dan 12,676 dengan nilai $\mathrm{P}$ sebesar 0,002 . Adapun nilai $\div_{\text {tabel }}^{2}$ pada taraf kesalahan $5 \%$ adalah sebesar 3,84 untuk pengujian pertama dan 5,99 untuk pengujian kedua. Berdasarkan hasil pengujian tersebut dapat diketahui bahwa $\div{ }_{\text {hitung }}^{2}>\div{ }_{\text {tabel }}^{2}$, yaitu 14,464 $>$ 3,84 dan 12,676> 5,99 dengan nilai P > 0,05. Dengan demikian, dapat dikatakan bahwa Ho ditolak dan Ha diterima. Penerimaan Ha tersebut menunjukkan bahwa ada hubungan antara pendapat Dinas dengan masyarakat maupun antara pendapat Dinas dengan piha swasta dalam hal kondisi sosial, ekonomi, dan politik. 
Dinas Pertambangan dan Energi Kabupaten Bulungan juga telah melibatkan pihak swasta. Hal ini melalui tersambungnya atau tersedianya listrik ke masyarakat maka biaya penerangan masyarakat dapat dihemat. Masyarakat dapat menggunakan teknologi-teknologi untuk bersosialisasi, bermasyarakat, berpolitik, dan meningkatkan usaha-usaha masyarakat yang menggunakan listrik (Hasil Wawancara 3, 2013).

\section{KECENDERUNGAN PARA PELAKSANA}

Sikap penerimaan atau penolakan dari Dinas Pertambangan dan Energi Kabupaten Bulungan sebagai instansi pelaksana teknik akan sangat banyak mempengaruhi keberhasilan implementasi yang dilaksanakan adalah kebijakan "dari atas" (top down) yang sangat mungkin para pengambil keputusannya tidak pernah mengetahui (bahkan tidak mampu menyentuh) kebutuhan, keinginan, atau permasalahan yang warga ingin selesaikan. Berikut penilaian informan mengenai kecenderungan pelaksana.

Proporsi pendapat responden mengenai kecenderungan badan pelaksana dapat juga dilihat pada gambar berikut.

\section{GRAFIK 6 PROPORSI PENDAPAT RESPONDEN TENTANG KECENDERUNGAN} BADAN PELAKSANA

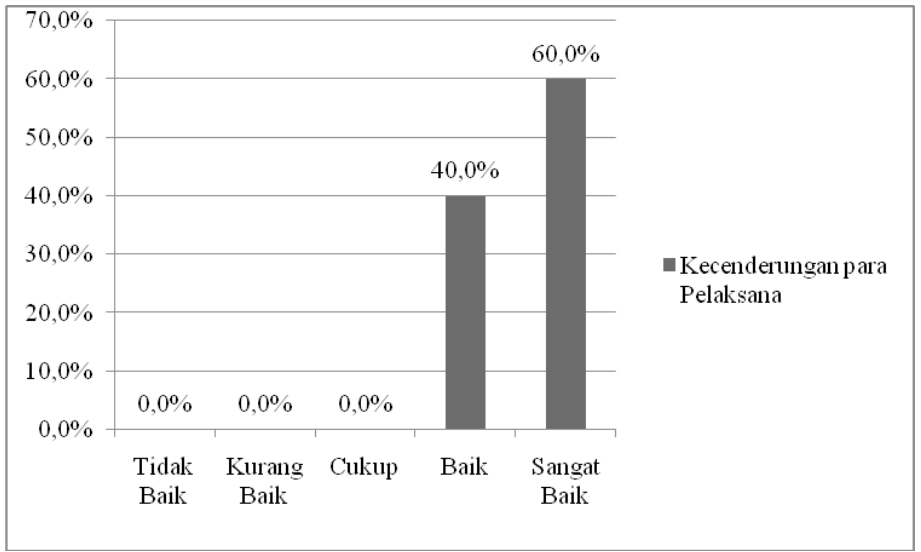


Berdasarkan tabel dapat dipahami bahwa Dinas Pertambangan dan Energi sebagai badan pelaksana memiliki kecenderungan yang sangat baik. Hal ini diketahui dari penilaian mayoritas responden terhadap aspek-aspek kecenderungan badan pelaksana yang tergolong sangat baik, yaitu sebanyak 21 orang (60\%).

Hasil analisis Chi Square terhadap jawaban responden mengenai Kecenderungan para pelaksana dapat dilihat pada tabel berikut.

\section{TABEL 7 KECENDERUNGAN PARA PELAKSANA}

\begin{tabular}{llll}
\hline Nilai & Pejabat Dinas & Masyarakat & Swasta \\
\hline Cukup & - & - & - \\
Baik & 23 & 23 & 21 \\
Sangat baik & 12 & 12 & 14 \\
Total & 35 & 35 & 35 \\
Chi Square & & 19.498 & 14.287 \\
Asymp. Sig. & 0.000 & 0.000 \\
Z2tabel $_{(0.95)=}$ & 3.84 & 5.99 \\
\hline
\end{tabular}

Sumber: data diolah (2013)

Tabel Tabel di atas menunjukkan nilai $\div_{\text {hitung }^{2}}^{2}=19,498$ dengan nilai $\mathrm{P}$ sebesar 0,000 untuk perbedaan antara pendapat Dinas dengan masyarakat dan 14,287 dengan nilai P sebesar 0,000. Adapun nilai $\div{ }_{\text {tabel }}^{2}$ pada taraf kesalahan $5 \%$ adalah sebesar 3,84 untuk kedua pengujian. Berdasarkan hasil pengujian tersebut dapat diketahui bahwa $\div_{\text {hitung }}^{2}>\div{ }_{\text {tabel }}^{2}$, yaitu 19,498 > 3,84 dan 14,287 > 3,84 dengan nilai $\mathrm{P}>0,05$. Dengan demikian, dapat dikatakan bahwa Ho ditolak dan Ha diterima. Penerimaan Ha tersebut menunjukkan bahwa ada hubungan antara pendapat Dinas dengan masyarakat maupun antara pendapat Dinas dengan piha swasta dalam hal kecenderungan para pelaksana.

Kecenderungan badan pelaksana juga dapat dipahami berdasarkan kutipan wawancara berikut. 
"Dinas Pertambangan perlu melakukan program berkelanjutan bersama instansi terkait agar pembangunan bidang kelistrikan dapat berfungsi secara optimal" (Hasil Wawancara Informan 1, 2013).

Berdasarkan hasil wawancara di atas dapat dihapami bahwa Dinas Pertambangan dan Energi Kabupaten Bulungan perlu melakukan program berkelajutan terkait pembangunan kelistrikan. Hal ini dilakukan agar pembangunan kelistrikan dapat dilaksanakan secara optimal, sesuai Bulungan. Kecenderungan implementasi Perda APBD Sektor Pertambangan dan Energi Kabupaten Bulungan juga dapat dipahami melalui kutipan berikut.

"Anggaran pembangunan kelistrikan berdasarkan Perda cukup baik. Harapannya agar dapat dilanjutkan dan ditingkatkan baik nilai, program, dan waktu pelaksanaan" (Hasil wawancara Informan 3, 2013).

Berdasarkan kutipan di atas dapat dipahami bahwa Dinas Pertambangan dan Energi Kabupaten Bulungan pada dasarnya sudah memiliki anggaran yang mencukupi. Dinas pertambangan dan Energi juga sangat memahami permasalahan di bidang kelistrikan yang terdapat di Kabupaten Bulungan, sehingga dapat mencari upaya penyelesaian masalah tersebut, melalui pelaksanaan program-program pembangunan kelistrikan.

\section{PEMBANGUNAN KELISTRIKAN}

Pembangunan kelistrikan di Kabupaten Bulungan dilakukan melalui peningkatan kapasitas dan ketersediaan energi listrik baik untuk rumah tangga maupun industri. Untuk tenaga listrik yang terjual, rumah tangga merupakan kategori pelanggan terbesar yang menggunakan tenaga listrik di kabupaten Bulungan, sedangkan untuk kategori Publik, Usaha, Industri, dan Sosial merupakan pengguna lainnya yang memiliki kebutuhan di bawah sektor rumah tangga. 
Pagu anggaran Dinas Pertambangan dan Energi Kabupaten Bulungan untuk tahun 2011 dan 2012 dapat dilihat pada tabel berikut.

TABEL 8 PAGU ANGGARAN DINAS PERTAMBANGAN DAN ENERGI KABUPATEN
\begin{tabular}{llll}
\multicolumn{3}{c}{ BULUNGAN } \\
\hline Tahun & Pagu Anggaran & Belanja Langsung & Belanja Tidak Langsung \\
\hline 2011 & $16,785,500,847$ & $3,311,691,372$ & $13,473,809,475$ \\
2012 & $50,844,268,614$ & $4,710,716,200$ & $46,133,552,414$ \\
Peningkatan & $303 \%$ & $142 \%$ & $342 \%$ \\
\hline
\end{tabular}

Sumber: APBD Kabupaten Bulungan (2011-2012)

\section{GRAFIK 7 PAGU ANGGARAN DINAS PERTAMBANGAN DAN ENERGI KABUPATEN} BULUNGAN

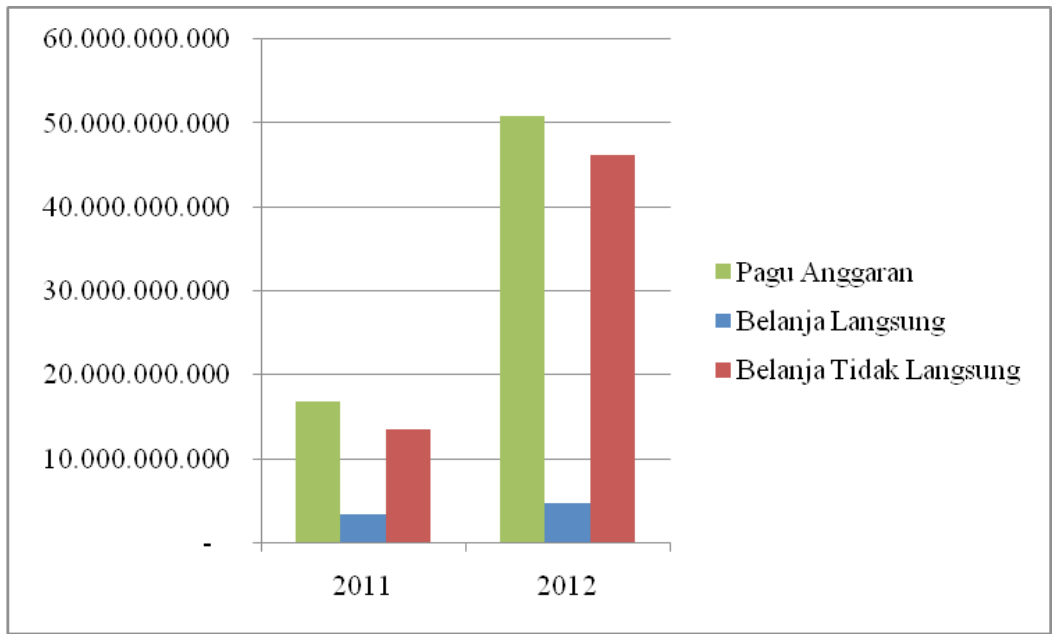

Dari data tersebut terlihat bahwa terjadi peningkatan yang cukup signifikan pada pagu anggaran Dinas Pertambangan dan Energi Kabupaten Bulungan. Peningkatan yang terjadi pada pagu anggaran tahun 2012 adalah sebesar 303\% dibandingkan tahun 2011. Pada tahun 2012, anggaran belanja langsung meningkat menjadi sebesar 142\% dibandingkan tahun 2011, sedangkan anggaran belanja tidak langsung meningkat sebesar 342\% dibandingkan tahun 2012. 
Namun demikian, besarnya peningkatan anggaran Dinas Pertambangan dan Energi tersebut tidak sejalan dengan peningkatan anggaran pembangunan kelistrikan. Anggaran pembangunan kelistrikan seakan berbanding terbalik dengan peningkatan yang terjadi pada peningkatan anggaran Dinas Pertambangan dan Energi secara keseluruhan.

Faktor Pendukung dan Penghambat Keberhasilan Implementasi Anggaran Pembangunan Kelistrikan

Dapat kita uraikan sebagai berikut:

a. Faktor Pendukung keberhasilan Implementasi Anggaran Pembanguan kelistrikan dapat dilihat dari aspek-aspek pengukuran keberhasilan implementasi, yaitu

1. Dukungan kebijakan Implementasi Anggaran Pembangunan dalam pelaksanaan Pembangunan kelistrikan.

2. Dukungan sumber-sumber kebijakan dalam implementasi Perda APBD Sektor Pertambangan dan Energi Kabupaten Bulungan dengan adanya anggaran yang besar dan peningkatan sumberdaya manusianya

3. Dukungan Komunikasi antar organisasi terkait, antara Dinas Pertambangan dan PT. PLN sertta BAPPEDA terjalin koordinasi yang baik.

4. Karakteristik badan pelaksana, dan kecenderungan para pelaksana tergolong baik dengan adanya program -program kegiatan yang terlaksanan dengan baik. Dan para pelaksana kegiatan sangat mendukung agar target yang diinginkan dapat tercapai.

5. Dalam hal kondisi ekonomi, sosial, dan politik dapat dikatakan bahwa aspek tersebut sangat mendukung keberhasilan Implementasi dengan tersedianya kebutuhan akan energi listrik tentunya akan menoingkatkan pertumbuhan ekonomi 
dan social serta kesatabilan politik.

b. Faktor-faktor yang masih menjadi penghambat bagi keberhasilan implementasi Perda APBD Sektor Pertambangan dan Energi Kabupaten Bulungan adalah

1. Jumlah aparat pelaksana di lapangan yang masih kurang memadai karena luasnya wilayah kabupten Bulungan.

2. Sarana dan prasarana yang diperlukan untuk pemeliharaan infrastruktur kelistrikan yang telah dibangun masih sangat kurang.

3. Adanya Program kegiatan yang tidak jalan akibat ketidak mampuan kontraktor dalam melaksanakan kegiatan sehingga perlu adanya pengawasan yang lebih ketat.

4. Tidak meratanya pembanguna Kelistrikan karena kondisi geografi yang luas dan banyak daerah yang tidak terjangkau dengan jalan karena dipisahkan dengan sungai sehingga membutuhkan penanganan yang lebih baik.

5. Adanya Keluhan-keluhan dari masyarakat mengenai seringnya pemadaman listrik dan rendahnya tegangan listrik. Oleh karena itu, diperlukan adanya pembangunan kelistrikan yang berkelanjutan di Kabupaten Bulungan.

6. Belum adanya peraturan khusus yang mengatur tentang Perda Pembangunan Kelistrikan.

\section{KESIMPULAN DAN SARAN}

Dalam penelitian ini menunjukkan bahwa pembangunan kelistrikan dengan Perda APBD Sektor Pertambangan dan Energi Kabupaten Bulungan perlu adanya peningkatan. Mengingat masih rendahnya implementasi karena pengaruh kondisi social, ekonomi dan politik di Kabupaten Bulungan. Diperlukan kerjasama antarinstansi pelaksana untuk mencapai pembangunan sarana prasarana yang terkait dengan pembangunan kelistrikan. Adanya factor 
pendorong dan penghambat dalam pelaksanaan implementasi juga harus dipikirkan secara baik-baik. Sebagai upaya peningkatan pembangunan kelistrikan di Kabupaten Bulungan.

Saran yang dapat diberikan terkait dengan hasil penelitian ini adalah sebagai berikut.

1) Bagi Dinas Pertambangan dan Energi Kabupaten Bulungan, diharapkan dapat melakukan pembangunan kelistrikan sesuai denganPerda APBD Sektor Pertambangan dan Energi Kabupaten Bulungan. Hal ini disebabkan implementasi Perda APBD Sektor Pertambangan dan Energi Kabupaten Bulungan dapat mempengaruhi kondisi sosial, ekonomi, dan politik di Kabupaten Bulungan. Bagi Dinas Pertambangan dan Energi kabupaten Bulungan juga diharapkan dapat melakukan peningkatan jumlah aparat pelaksana lapangan, serta melakukan berbagai upaya untuk meningkatkan kuantitas dan kualitas sarana dan prasarana terkait pembangunan kelistrikan. Perlunya koordinasi untuk pembentukan Perda tentang kelistrikan yang mengatur tentang pembangunan di bidang kelistrikan.

2) Bagi aparat pada Dinas Pertambangan dan Enegeri Kabupaten Bulungan, diharapkan dapat meningkatkan kinerja maupun kompetensinya. Peningkatan kinerja dan kompetensi aparat pada Dinas Pertambangan dan Enegeri Kabupaten Bulungan tentunya akan turut mempengaruhi keberhasilan implementasi Perda APBD Sektor Pertambangan dan Energi Kabupaten Bulungan. Peningkatan kinerja dan kompetensi aparat pada Dinas Pertambangan dan Enegeri Kabupaten Bulungan dapat dilakukan melalui pembelajaran langsung di lapangan, dan juga dengan mengikuti pelatihan atau bimbingan. 


\section{DAFTAR PUSTAKA}

\section{BUKU}

Akhmad, Jazuli. 2002. Metodologi Penelitian Bisnis. Yogyakrata: STIE Widya Wiwaha.

Arikunto, Suharsimi. 2010. Prosedur Penelitian: Suatu Pendekatan Praktik Edisi Revisi 2010. Jakarta: Rinneke Cipta.

Baedhowi. 2004. Implementasi Kebijakan Otonomi Daerah Bidang Pendidikan (Studi Kasus di Kabupaten Kendal dan Kota Surakarta. Disertasi tidak diterbitkan Universitas Indonesia.

Bastian, Indra. 2005. Akuntansi Sektor Publik Suatu Pengantar. Jakarta: Erlangga.

Creswell, John. 2010. Research Design: Pendekatan Kualitatif, Kuantitatif, dan Campuran. Yogyakarta: Pustaka Pelajar.

Dwi T. M, Desia Berty. 2011. Analisis Poor Pro Budget (Studi Alokasi dan Implementasi Anggaran pada Sektor Kesehatan Kabupaten Kebumen Tahun Anggaran 2009-2010). Tesis tidak diterbitkan. Universitas Diponegoro.

Dye, Thomas R. 1981. Understanding Publik Policy. Englewood Cliffs, NY: Prentice-Hall International, Inc

Goggin, Malcolm L, Ann O’M. Bowman, James. P. Lester, and Laurence J. O'Toole. 1990. Implementation Theory \& Practice: Toward a Third Generation. Illions: Glenview.

Grindle, Marilee S. 1980. Politics and Policy Implementation in the third world. Princeton, NJ: Princeton University.

Halim Abdul \& Damayanti, Theresia. 2007. Pengelolaan keuangan daerah (seri Bunga rampai Manajemen Keuangan daerah. Yogyakarta: UPP AMP YKPN.

Harahab, Sofyan Syarif. 2004. Manajemen Kontemporer. Jakarta: Raja Grafindo Persada. Indriantoro, Nur dan Bambang Supomo. 2002. Metodologi Penelitian Bisnis. Yogyakarta: BPFE UGM.

Kristidjo, Hari dan Nugroho, Hanan. 2003. Menuju Pemanfaatan Energi Yang Optimum Di Indonesi: Pengembangan Model Ekonomi Energi Dan Identifikasi Kebutuhan Infrastruktur Energi. Jakarta: karya tulis BAPENNAS.

Mardiasmo. 2002. Otonomi dan Manajemen Keuangan Daerah. Yogyakarta: Andi Offset.

Miles, M.B dan Hubermann, A.M. 2009. Analisis data kualitatif, buku sumber tentang metode-metode baru. Jakarta: UI Press.

Moleong, Lexy J. 2001. Metodologi Penelitian Kualitatif. Bandung: remaja Rusda Karya. Persons., Talcott. 2005. Desocial system. New York: free Press.

Pemerintah Republik Indonesia. 2002. "Undang-Undang No. 20 tahun 2002 tentang ketenaga listrikan". Jakarta: Sekretaris Negara.

Pierrakatis kayeriakos. 2009. The Suistanable Grow The Paradigm: Implications For Tecnology And Policy. Thesis (S.M. In Technology and Policy).

Poerwadarminta, W. J. S. 1994. Kamus umum bahasa Indonesia. Jakarta: Balai Pustaka. Sugiyono. 2010. Memahami Penelitian Kualitatif. Bandung: Alfabeta.

Sugiyono. 2011. Metode Penelitian Kuantitatif, Kualitatif dan R\&D. Bandung: CV Alfabeta. Suryaningrat, Bayu. 1999. Wewenang, Tugas Dan Tanggung Jawab Pegawai. Jakarta: 
Patco.

Tamar, Muhammad. 2011. Analisis Implementasi Program Pendidikan Gratis Di Kecamatan Malili Kabupaten Luhu Timur. Thesis tidak di terbitkan. Universitas Hassanudin.

Tangkilisan, hassel Nogi S. 2003. Kebijakan Publik yang membumi. Yogyakarta: Lukman Offset dan YPAPI Yogyakarta.

Wahab, Abdul. 1997. Analisis Kebijakan Dari Formulasi Ke Implementasi Kebijakan Negara. Edisi ke II. Jakarta: Bumi Aksara.

Winarno, Budi. 2008. Kebijakan Publik; Teori Dan Proses, Edisi Revisi. Yogyakarta: Media Pressindo.

Bapan Pusat Statistik kabupaten Bulungan. 2010. Statistik Daerah Kabupaten Bulungan Tahun 2010. Bulungan: BPS.

\section{JURNAL}

Avionita, Venni. 2012. "Pengaruh Anggaran Berbasis Kinerja Terhadap Kinerja Program Peningkatan Disiplin Aparatur Instansi Pemerintah Daerah". Bandung: Universitas Widyatama.

Bastian, Indra. 2008. "Keterlambatan APBD Dalam Analisis Siklus". Jurnal Akuntansi dan Keuangan Volume 7, Nomor 2, September 2008, hlm. 115-130

Handayani, bestari dewi. 2009. "Pengaruh Reformasi Penyusunan Anggaran Terhadap Kualitas Apbd Kota Semarang". Jurnal dinamika akutansi Vo. 1, No. 1, Maret 2009, PP. 31-40.

Permana, Ryan. 2012. "Analisis Implementasi Penganggaran Berbasis Kinerja: Studi Kasus Pada Universitas Indonesia". Universitas Indonesia.

Sharon Sumenge, Ariel. 2013. "Analisis Efektifitas Dan Efisiensi Pelaksanaan Anggaran Belanja Badan Perencanaan Pembangunan Daerah (Bappeda) Minahasa Selatan". Jurnal EMBA Vol.1 No.3 September 2013.

Wibowo, Muhammad Gafur. 2012. "Kebijakan Anggaran Pemerintah Bagi Sektor Pendidikan". EKBISI, Vol. VII, No. 1, Desember 2012. 